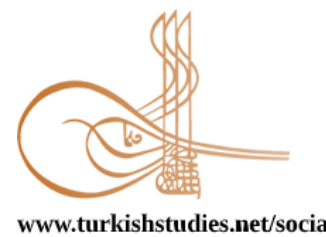

Turkish Studies - Social Sciences

\title{
Engellilerde Sosyal Dışlanma Ölçeğinin (ESDÖ) Geliştirilmesi: Geçerlilik ve Güvenirlik Çalışması
}

\author{
Developing the Social Exclusion Scale for the Persons with Disabilities (SESPD): Validity
} and Reliability Study

Yunus Bucuka*

\begin{abstract}
There are various problems in the field of disability. Each individual with disbailities is faced with these problems in accordance with his own conditions. Social exclusion, which is a phenomenon that covers many of these problems, is very important for understanding the extent and effects of the problems experienced by the disabled. Therefore, understanding the social exclusion problem experienced by people with disabilities will contribute to providing formal or informal support and services to be provided more effectively. An application was made to the Scientific Research and Publication Ethics Board of Bingöl University for the study and approval was obtained with the decision numbered E.1101 dated 14.01.2020. Accordingly, it was aimed to develop the "Social Exclusion Scale for the Disabled" in order to determine the social exclusion experienced by the disabled. 546 disabled individuals were included in the study. The draft scale, which is planned to be developed, was answered by 50 people with disabilities and the scale was subjected to exploratory and confirmatory factor analyzes in order to determine the structural validity. As a result of the exploratory factor analysis, a scale consisting of twenty-five items with these sub-dimensions: exclusion from participation in social life, exclusion from access to basic services, and income deprivation and exclusion from the economic life. The total variance rate of the scale was determined to be $40.94 \%$. The factor loads of the items in the scale were between .40 and .75 . As a result of the confirmatory factor analysis, it was determined that the scale has sufficient fit index values. Cronbach Alpha coefficients of the sub-dimensions of the scale were determined as $.80, .78$ and .79. In line with these analyzes, it has been confirmed that the Social Exclusion Scale for the Disabled is a valid and reliable measurement tool that can be used to determine the social exclusion experienced by the disabled.
\end{abstract}

Structured Abstract: Disability exists as an important problem in all societies. This problem also has a historical feature. In the coming years, this phenomenon will exist in all societies with different characteristics and statistical features. According to the World Health Organization, it is thought that there are more than a billion disabled people in the world. In the coming years, the issue of basic services to be provided to disabled people will gain more importance.

Disability has the characteristic of being beyond time and space. It will be present in all societies in the future as in the past. However, the problems encountered will of course differ according to time. Although there are many national and international mechanisms to support them today, problems regarding

\footnotetext{
* Dr. Öğr. Üyesi, Bingöl Üniversitesi, Fen Edebiyat Fakültesi, Sosyal Hizmet Bölümü Asst. Prof. Dr., Bingöl University, Fakulty of Science and Letters, Department of Social Work ORCID 0000-0003-3001-2646

ybucuka@bingol.edu.tr

Cite as/ Atıf: Bucuka, Y. (2020). Engellilerde sosyal dışlanma ölçeğinin (ESDÖ) geliştirilmesi: geçerlilik ve güvenirlik çalışması. Turkish Studies - Social, 15(5), 2427-2443. https://dx.doi.org/10.47356/TurkishStudies.43181 Received/Geliş: 26 April/Nisan 2020 Accepted/Kabul: 20 August/Ağustos 2020 Copyright $($ INTAC LTD, Turkey

Checked by plagiarism software

Published/Yayın: 30 August/Ağustos 2020 CC BY-NC 4.0
} 
social or political rights and inclusion of disabled people in social life remain current under the conditions of each country.

Among the important resources that can be used to define disability is legislation on disability. Social Services Law No. 2828 comes first in this legislation. The mentioned law defines the disabled as "the person who needs to be protected, care, rehabilitation, counseling and support services because he / she loses his physical, mental, spiritual, emotional and social abilities in various degrees as a result of any disease or accident from birth or later."

In addition to national legislation, the most important of these is the World Health Organization's ICF (International Classification of Functioning, Disability and Health - International Functionality, Disability and Health Classification) approach disability is a biopsychosocial phenomenon. Therefore, disability includes both the insufficiency of individual activities and the limited participation of socially built environment and culture (Uluocak \& Aslan, 2012: 41-44).

In the classifications on disability, there are different classifications in the related literature, although there are very few differences. However, in many studies, it is accepted that there are seven basic types of disability. These are sight, mental, orthopedic, language and speech, hearing, mental and emotional and chronic disability. Although they are divided into different categories, there are many common problems that disabled people experience. These problems are often above the level that disabled people can withstand alone. Therefore, it is important to identify the problems experienced by the disabled and then provide the necessary support. Accordingly, first of all, the social exclusion phenomenon, which collects the problems experienced within its body, should be measured.

There are many disadvantaged groups experiencing social exclusion. Silver (1995: 74-75) states these groups in which various studies are conducted in the literature: Long-term or permanent unemployed, underpaid people, the poor, substance addicts, criminals, children growing up in problem families, child workers, refugees racial, religious and ethnic minorities, women, individuals stigmatized in any respect are just some of these groups. In addition, families with disabilities and individuals with disabilities are also socially excluded in many respects.

Disabled people are an important disadvantaged group that has to deal with a wide range of problems. Although these problems have health and treatment dimensions, they also have many other dimensions such as social, economic, spatial, political and spiritual.

This study aims to develop a scale in order to identify and measure problems experienced by the disabled and social exclusion. An application was made to the Scientific Research and Publication Ethics Board of Bingöl University for the study and approval was obtained with the decision numbered E.1101 dated 14.01.2020.

The number of samples is 546. Sample selection was determined by random sample type. Participants are individuals with disabilities over the age of eighteen with a disability rate of at least $40 \%$.

In the preparation process of the scale, firstly national and international literature was searched and necessary data sources were determined. Studies on the problems experienced by the disabled have been reviewed. In this process, the draft scale was examined by seven faculty members who also had academic studies on scale development and use at Bingöl University. In addition, the intelligibility, spelling and expression features of the scale were reviewed.

Survey practitioners were given information about the purpose, importance and scale questions of the research before implementing the field research. In addition, the directive created to define various principles and processes was introduced and shared in the survey applications.

The data obtained from these forms were analyzed with SPSS and Amos programs. Firstly, to determine the psychometric properties of the data, it was examined whether the distribution of the data was normal by statistical analysis. Accordingly, the Skewness and Kurtosis values of the items were examined and it was found that the distribution was in normal dimensions since the results were between -1.50 and +1.50 . After this process, the construct validity of the scale was analyzed by exploratory factor analysis and confirmatory factor analysis . 
As a result of factor analysis of the scale items, the Scree plot chart was reviewed and it was deemed appropriate to have three sub-dimensions. Twenty five items were found to be relevant in total consisting eleven items in exclusion from participation in social life, seven items in exclusion from access to basic services, and seven in income exclusion and economic exclusion. When the factor loads of all items are analyzed, the lowest value is .408 and the highest value is .756.

The total variance rate of the scale was determined as $40.94 \%$. The factor loads of the scale items ranged between .40 and .75 . In the confirmatory factor analysis, the scale had sufficient fit index values and the Cronbach Alpha coefficients of the sub-dimensions of the scale were determined as .80, .78 and .79. In the factor analysis of the scale, the KMO value was .88 and the Barlett test $\chi 2$ value was 5259,337 (p <.001); Cronbach-alpha reliability coefficient was found to be .88 which is significant and acceptable in the analysis of the coefficient, and the scale's fit index $\left(x^{\wedge} 2 / \mathrm{sd}=2,000, \mathrm{p}=.00\right)$. As a result of the reliability and validity analyzes, it was revealed that the scale is a applicable tool.

Keywords: Sociology, Disabled People, Social Exclusion, Scale, Validity, Reliability

Öz: Engellilik alanında çok çeşitli sorunlar bulunmaktadır. Her engelli birey kendi koşulları ölçüsünde bu sorunlarla yüz yüze gelmektedir. Bu sorunların birçoğunu kapsayan bir olgu olan sosyal dışlanma, engellilerin yaşadıkları sorunların boyut ve etkilerini anlamak hususunda oldukça önem arz etmektedir. Bu nedenle engelli bireylerin yaşadıkları sosyal dışlanma sorununun anlaşılması, onlara sunulacak formel ya da enformel destek ve hizmetlerin daha etkin yürütülmesini sağlamaya katkı sunacaktır. Bu doğrultuda, engellilerin yaşadıkları sosyal dışlanmanın tespit edilebilmesi için "Engellilerde Sosyal Dışlanma Ölçeği”"nin geliştirilmesi amaçlanmıştır. Çalışma için Bingöl Üniversitesi Bilimsel Araştırma ve Yayın Etiği Kurulu Başkanlığına başvurulmuş ve 14.01.2020 tarih ve E.1101 sayılı karar ile uygulanma konusunda onay alınmıştır. Çalışmaya 546 engelli birey dahil edilmiştir. Geliştirilmesi düşünülen taslak ölçek 50 madde olarak bu engelli bireylerce cevaplanmış ve elde edilen sonuçlar doğrultusunda ölçek, yapısal geçerliliğin belirlenmesi amacıyla açımlayıcı ve doğrulayıcı faktör analizlerine tabi tutulmuştur. Açımlayıcı faktör analizinin sonucunda, yirmi beş maddeden ve toplumsal hayata katılımdan dişlanma, temel hizmetlere erişimden dışlanma ile gelir yoksunluğu ve ekonomik alandan dişlanma olmak üzere üç boyuttan oluşan ölçek elde edilmiştir. Ölçeğin toplam varyans oranı \%40,94 olarak tespit edilmiştir. Ölçekteki maddelerin faktör yükleri .40 ile .75 arasında değer almışlardır. Doğrulayıcı faktör analizi neticesinde ölçeğin yeterli uyum indeksi değerleri taşıdığı belirlenmiştir. Ölçeğin alt boyutlarının Cronbach Alpha katsayıları .80, .78 ve .79 olarak tespit edilmiştir. Bu analizler doğrultusunda, Engellilerde Sosyal Dışlanma Ölçeği'nin engellilerin yaşadıkları sosyal dışlanmayı belirlemede kullanılabilecek geçerli ve güvenilir bir ölçme aracı olduğu doğrulanmıştır.

Anahtar Kelimeler: Sosyoloji, Engelliler, Sosyal Dışlanma, Ölçek, Geçerlilik, Güvenirlik

\section{Giriş}

Engellilik tüm toplumlarda önemli bir olgudur. Önümüzdeki y1llarda bu olgu tüm toplumlarda farklı nitelik ve istatistikî özelliklere sahip olarak bulunacaktır. Dünya sağlık verilerine göre dünyada bir milyardan fazla engelli olduğu düşünülmektedir. Yaklaşık iki yüz milyonu engelli ise günlük yaşamlarında birçok ciddi zorlukla karşılaşmaktadır (Dünya Sağlık Örgütü [DSÖ], 2011). Türkiye'de ise nüfusun \%12,29 oranında engelli olduğu bilinmektedir (Devlet İstatistik Enstitüsü Başkanlığı [DİE], 2002). İlerleyen yıllarda engellilere sunulacak temel hizmetler hususu daha da önem kazanacaktır. Bu nedenle engellilere ilişkin bilimsel literatürün geniş̧letilmesi de önem arz etmektedir.

Engellilik, evrensel bir olgu niteliğine sahiptir. Geçmişte olduğu gibi gelecekte de tüm toplumlarda mevcut olacaktır. Bununla beraber karşılaşılan sorunlar elbette zaman göre farklılaşacaktır. İlkçağlarda engelliler, suç, ceza, günah gibi kavramlarla ilişkilendirilmiştir. Bu nedenle, şehirlerden uzaklaştırılmış ve yalnızlığa mahkûm edilmişlerdir. Dilencilik için kullanılmış hatta kurban edilmişlerdir. Yakın geçmişte Nazi Almanya'sında öjenik uygulamalar için deney malzemesi olarak kullanılmış, modern zamanlarda otomasyon üretimiyle, istenmeyen "işçi" olarak 
emek piyasasından uzaklaştırılıp marjinalleştirilmişlerdir. Her ne kadar günümüzde onları destekleyecek birçok ulusal ve uluslararası mekanizma bulunsa da, hala sosyal ya da politik haklar ve sosyal hayata dahil olma konusunda sorunlar, her ülkenin koşulları çerçevesinde, güncelliğini korumaktadır (Okur ve Erbilerdugan, 2010: 249-252; Mitchell ve Snyder, 2003: 844-858).

Engelliliği tanımlamada kullanılabilecek önemli kaynaklar arasında engellilikle ilgili mevzuat bulunmaktadır. Çünkü engellilere yönelik sürdürülen kamu hizmetlerinde olgunun tanımlanma gerekliliği önem arz eder. Bu mevzuatın başında 2828 sayılı Sosyal Hizmetler Kanunu gelmektedir. Söz konusu kanun engelliyi; "doğuştan veya sonradan herhangi bir hastalık ya da kaza sonucu bedensel, zihinsel, ruhsal, duygusal ve sosyal yeteneklerini çeşitli derecelerde kaybetmesi nedeniyle normal yaşamın gereklerine uymama durumunda olup korunma, bakım, rehabilitasyon, danışmanlik ve destek hizmetlerine ihtiyacı olan kişi" olarak tanımlamaktadır. Bu tanımı pekiştirecek nitelikte, 5378 Engelliler Hakkında Kanununun 3/c maddesinde engellilerin topluma etkin kat1lımının altı çizilerek şunlar belirtilmektedir: "Fiziksel, zihinsel, ruhsal ve duyusal yetilerinde çeşitli düzeyde kayıplarından dolayı topluma diğer bireyler ile birlikte eşit koşullarda tam ve etkin katılımını kısıtlayan tutum ve çevre koşullarından etkilenen bireydir." (TBMM, 2005, güncelleme 2014).

Ulusal mevzuatın yanında, uluslararası literatürde de engelliliğin tanımlanmasına dair çeşitli alternatifler ileri sürülmüştür. Ancak, bunların en önemlisi, tüm dünya çapında kabul gören, Dünya Sağlık Örgütü'nün ICF (International Classification of Functioning, Disability and Health Uluslararası işlevsellik, Engellilik ve Sağlık Sınıflandırması-) yaklaşımıdır. Bu yaklaşıma göre, engellilik, birey ile çevre etkileşimin ürünüdür. ICF yaklaşımında engellilik, biyopsikososyal bir olgudur. Dolayısıyla, engellilik hem bireysel faaliyet yetersizliğini hem de toplumsal olarak inşa edilmiş çevre ve kültürün ürettiği katılım kısıtlılı̆̆ını içermektedir (Uluocak ve Aslan, 2012: 4144). Bu noktada engelliliği kuramsal olarak değerlendiren iki önemli modelden bahsetmek yerinde olacaktır. Bu modeller medikal (tıbbi) ve sosyal modellerdir. Medikal modele göre engellilik, çoğunlukla bireyseldir. Literatüre hakim olan terminoloji tıbbidir. Temel vurgu bireylerin bedenlerinde sorun olduğudur, sorun biyolojiktir. Dolayısı ile bütün çabalar ve çözümler bireylerde odaklanmıştır. Onun tedavi edilmesi, iyileştirilmesi gibi kurumsal bakım ve tıbbi rehabilitasyon merkezli çözümlere yönelinmektedir. Engellilerin toplumsal hayatları dikkate alınmaz (Burcu, 2010: 75). Bu yaklaşıma karşın, sosyal model engelliliği bireysel boyuttan toplumsal alana taşır. Sosyal modelin literatüründe artık toplum, siyaset, özgürleşme merkezde olan kavramlardır. Engelliliğin büyük oranda sosyal dışlanmanın bir sonucu olduğu da ileri sürülmektedir. Sorun bireylerden çok toplumsal yapıdadır. Çünkü engellilik, sosyal yapıya etki etmiş sosyal dışlama çerçevesinde ortaya çımaktadır. Analiz edilmesi gereken bu yap1 ve onun yeniden organizasyonudur (Shakespeare, 2011: 59-60).

Engelliliğe dair sınıflamalarda, ilgili literatürde, çok az farlılıklar da olsa, değişik tasnifler bulunmaktadır. Ancak birçok araştırmada engelliliğin yedi temel türü olduğu kabul edilmektedir. Bunlar görme, zihinsel, ortopedik (kas ve iskelet sisteminde yetersizlik, serebral palsi, kifoz, spina bifida gibi), dil ve konuşma (kekemelik, afazi gibi), işitme, ruhsal ve duygusal (depresyon, şizofreni gibi) ile süreğen (kanserler, kalp-damar, solunum sistemi hastalıkları gibi) engelliliktir (TÜİK, 2010; Özürlüler İdaresi Başkanlığ1, 2010). Turnbull, Turnbull, Wehmeyer ve Shogren (2020) ise, daha geniş bir şekilde engelliliği şöyle sınıflamaktadırlar: öğrenme yetersizliği olan bireyler, konuşma ve dil bozukluğu olan bireyler, duygusal ve davranışsal bozukluğu olan bireyler, dikkat eksikliği ve hiperaktivite bozukluğu olan bireyler, zihinsel yetersizliği olan bireyler, otizmli bireyler, çoklu yetersizlik ve travmatik beyin hasarı olan bireyler, fiziksel yetersizliği ve diğer sağlık yetersizlikleri bozukluğu olan bireyler, işitme yetersizliği olan bireyler ve görme yetersizliği olan bireylerdir.

Farklı kategorilere ayrılsalar da engellilerin yaşadıkları birçok ortak sorun bulunmaktadır. $\mathrm{Bu}$ sorunlar çoğu zaman engellilerin tek başına karşı koyabilecekleri düzeyin üstünde olmaktadır. 
Dolayısıyla engellilerin yaşadıkları sorunları tespit etmek ve bunun ardından gerekli destekleri sunmak önem arz etmektedir. Bu doğrultuda öncelikle yaşanılan sorunları önemli ölçüde kendi bünyesinde toplayan sosyal dişlanma olgusunun ölçülmesi gerekmektedir.

Sosyal dışlanma, topluma dahil edilme mekanizmasının zayıflayarak, sosyal entegrasyonun ve (De Haan, 1999: 4-7) sosyal mesafe, reddetme ve sosyal destek ağlarının eksikliğini de içeren dinamik bir süreci ifade eder (Silver ve Miller, 2003: 12). Bununla beraber sosyal dışlanma tanımları, ulusal bağlama ve sosyal ve politik paradigmalara göre anlam kazanmaktadır (Silver, 2007: 4419). Bir süreç olarak değerlendirildiğinde, ekonomik, sosyal, kültürel veya politik kaynakların, hakların, malların ve hizmetlerin eşit olmayan bir şekilde dağıtımına vurgu yapar (Levitas, Pantazis, Fahmy, Gordon, Lloyd-Reichling ve Patsios, 2007: 25).

Dışlanma sürecinde, kişiler, aileler, gruplar; sosyal, ekonomik ve politik toplumsal faaliyetlere dahil olma, temel kamusal hizmetlerden yararlanma konusunda gereken destekten yoksun kalmaktadırlar. Böylece toplumun geneline sunulan kaynak ve firsatlardan, uzun ya da kısa bir zaman, uzak kalmaktadırlar (Pierson, 2009: 12). Dolayısıyla, dışlanmaya maruz kalanlar, yoksunluğu üretecek bir kısır döngüye uğrar, bu durumda onların topluma katılmalarını engeller, etkisine bağlı olarak da dışlanan kişiler bu sorunlarla başa çıkma olanağı dahi bulamayabilirler (Bolger ve Morago, 2016: 98).

Sosyal dışlanma yaşayan birçok dezavantajlı grup bulunmaktadır. Silver (1995: 74-75) literatürde üstünde çeşitli araştırmaların yapıldığı bu grupları belirtmektedir: Uzun süreli veya sürekli işsizler, düşük ücretliler, yoksullar, madde bağımlıları, suçlular, cezaevi mahkûmları ve sabıka kaydı olanlar, sorunlu ailelerde büyüyen çocuklar, çocuk işçiler, mülteciler ve göçmenler, ırksal, dinsel ve etnik azınlıklar, kadınlar, herhangi bir açıdan damgalanmış bireyler bu gruplardan sadece bazılarıdır. Bunlara ek olarak, engelliler ve engelli bireylere sahip aileler de birçok açıdan sosyal dışlanmaya uğramaktadırlar.

Teorik olarak sosyal dışlanma, önemli analitik potansiyele sahiptir. Cinsiyet, etnik köken, kast, din, sosyal sınıf vb. ile ilişkili sosyal tabakalaşma sistemleri arasında faaliyet gösteren çoklu dışlayıcı süreçler arasındaki etkileşime odaklanabilir (Mathieson vd, 2008: 29).

Sosyal dışlanma sürecini belirleyen önemli nedenler bulunmaktadır. Ancak Pierson (2009: 13) bunlardan beşini ön plana çıkarmaktadır: yoksulluk ve düşük gelir, iş piyasasına erişim eksikliği, yetersiz sosyal destek ve ağlar, yerel alanın veya yaşanılan muhitin etkisi, temel toplumsal hizmetlerden dışlanmadır.

Düşük gelir günümüzde sosyal dışlanmanın temel itici gücüdür. İşgücü piyasasına katılamama genellikle sosyal dışlanmanın temel bir göstergesi olarak kabul edilir. İşsizlik; evsizlik, sağlık, suç, uyuşturucu ve alkol sorunları gibi dışlanmanın diğer boyutlarını da etkiler. Ayrıca, dışlanma demografik, ekonomik, sosyal ve davranışsal faktörlerin karmaşık bir etkileşimi olarak kabul edilir (Bradshaw, Kemp, Baldwin ve Rowe, 2004: 2-3). Ancak sosyal dişlanma salt ekonomik faktörlere indirgenemez. Ekonomik faktörler sosyal dışlanmanın önemli bir yönüdür. Bunlarla beraber, sosyal olarak, siyasi katılım kanallarından kopmak ve resmi iletişim kanallarına olan güvensizlik, toplumsal düzensizlik, çevresel bozulma, yerel hizmetlerin geri çekilmesi, gittikçe gerileyen kamu hizmetleri ve yerel destek ağlarının çöküşü bulunmaktadır (Percy-Smith, 2000: 10).

Scharf, Phillipson, Kingston ve Smith (2001: 303-315) sosyal dışlanmayı beş temel boyutta değerlendirmektedir. Bunlar sosyal ilişkilerden (eş ve çocuklarıyla yakın ilişki vb.), kültürel faaliyetlerden (tiyatro, konser, sinemaya gitme vb.), toplumsal faaliyetlerden (sivil toplum organizasyonuna üye olma, seçimlerde oy kullanma vb.), temel hizmetlere erişimden (eğitim, sağlık vb.) ve yakın çevreden (arkadaşlık, komşuluk vb.) dışlanmadır. 
$\mathrm{Bu}$ boyutlandırmaya yakın bir şekilde, Percy-Smith (2000: 9), sosyal dişlanmanın boyutlarını yedi boyut olarak tasnif etmektedir. Bunlar; ekonomik boyut (uzun süreli işsizlik, çalışmayan aile bireyleri, gelir yoksulluğu vb.), sosyal boyut (istenmeyen ergen hamilelikleri, evsizlik, suç, asi gençlik vb.), politik boyut (politik hakların yetersizliği, yabancılaşma/politik süreçlerde güven eksikliği vb.), çevresel boyut (izolasyon, kirlilik, yerel hizmetlerde yetersizlik vb.), bireysel boyut (mental ve fiziksel rahatsızlıklar, eğitimde başarısızlık, düşük benlik saygısı, güvenin kaybedilmesi vb.), mekansal boyut (hassas nitelikteki grupların marjinalleştirilmesi vb.) ve grup (altı çizilen özelliklerin yaşlılar, engelliler, etnik azınlıklar gibi belirli gruplara yoğunlaşması) boyutlarıdir.

Sosyal dışlanmayı ölçmeye yönelik mevcut yaklaşımlar bazı sınırlamalardan muzdariptir. Mathieson ve arkadaşlarına (2008: 48) göre bunlar: paylaş1lan bir tanımın bulunmaması, dahil edilecek göstergeler ve alanlar/boyutlar üzerinde fikir birliği eksikliği, göstergelerin seçimi, kalitesi ve göstergelere dahil edilen öğelerin sosyal dışlanmanın nedenleri, risk faktörleri veya sonuçları olup olmadığı konusunda endişe, dışlanmayı ölçmek için tasarlanmamış anketlerden elde edilen göstergeler ile ölçmek istedikleri "sosyal dışlanma" boyutları arasında yanlış eşleşme, veri toplamanın maliyeti ve yöntem karmaşıklığı gibi önemli hususlardır. Ayrıca Sapancalı (2005: 57)'da sosyal dışlanmanın ölçümü için geliştirilen veri toplama araçlarının büyük oranda onun niceliksel boyutlarına odaklandıklarını, çok boyutlu yapısı gereği sayılaştıılabilir özelliklerinin yanı sıra, niteliksel bakımdan ölçümü zor olacak unsurları taşıdığının önemini vurgulamaktadır.

Klasen (1998: 9), sosyal dişlanmanın kesin ölçütlerini belirlemenin zor olduğunu belirtmektedir. Ayrıca, sosyal dışlanmanın, kapsamını veya yoğunluğunu elde edebilecek tek bir ölçüm aracıda yoktur. Dahası, sosyal dışlanma nesnel ve öznel özellikler içerdiğinden, çerçevesini belirlemek de zor olacaktır. Dolayısıyla, dışlanmayı doğrudan ölçme girişimleri, bireyleri topluma dahil etmenin bir başlangıç noktası olarak da değerlendirilebilir. Bu nedenle, Bhalla ve Lapeyre (1997: 431), sosyal dışlanmanın ölçülmesine yönelik metodolojiler ve göstergeler geliştirmek için, araştırmaların yapılması ve ulusal veri tabanlarının oluşturulması gerektiğini önemle vurgulamaktadırlar.

Sosyal dışlama konusunu engellilik bağlamında ölçmeyi gerçekleştiren ölçme araçlarının sayısının sınırlı olduğu anlaşılmaktadır. Özellikle ülkemizin kültürel özelliklerine uygun bir ölçme aracının geliştirmesi engellilik hususunda sosyal dışlanmanın hangi boyutlarda gerçekleştiğine de 1şık tutacaktır. Bu nedenle bu araştırmanın amacı engellilerin yaşadıkları dışlanmanın niteliğini ve düzeyini ölçmektir. Engelliler çok çeşitli sorunla baş etmek durumunda olan önemli bir dezavantajlı gruptur. Engelliler kendi aralarında çok farklı olarak tasnif edilmektedirler. $\mathrm{Bu}$ durumlar da onların karşı karşıya kaldıkları sorunları çeşitlendirmektedir. Bu sorunlar onların sağlık ve tedavi boyutları taşımakla birlikte, toplumsal, ekonomik, mekansal, siyasal ve ruhsal gibi daha birçok boyutlara da sahiptir. Dolayısı ile engellilerin yaşadıkları sorunların tasnif edilerek sistematik bir şekilde incelenmesi gerekmektedir. Bu çalışma bahsedilen hususlarda engellilerin yaşadıkları ve sosyal dışlanma kapsamına alınabilen sorunları tespit edip derecelendirmek amacıyla bir ölçek geliştirmeyi hedeflemektedir. Ayrıca bu ölçek çalışması engellilerin yaşadıkları sorunların neler olduğu ve bunların nasıl boyutlandırılacağını ortaya çıkarmayı sağlamayı da amaçlanmaktadır.

\section{Yöntem}

Bu bölümünde çalışmanın araştırma grubu, bu grubun bazı demografik özellikleri, ölçeğin geliştirilmesi, gerekli verilerin toplanması ve analiz süreci yer almaktadır.

\section{Çalışmanın Araştırma Grubu}

$\mathrm{Bu}$ çalışmanın araştırma grubu 546 engelli bireyden oluşmaktadır. Araştırma grubunun yeterliliği konusunda Alpar (2013: 290) ölçek maddelerinin sayısı ile uygulanacak kişi sayısının oranının on olması gerektiğini belirtmektedir. Geliştirilen ölçek madde sayısı, araştırmaya 
başlarken, elli olduğundan belirlenen araştırma grubunun sayı bakımından uygun olduğu söylenebilir. Araştırma grubunu, çalışmanın amacına uygunluk bakımından tesadüfî/rastgele örneklem türü ile belirlenmiştir. Araştırma grubuna ait bazı demografik özellikler tablo l'de verilmiştir.

Tablo 1: Araștırma Grubunun Bazı Demografik Özellikleri

\begin{tabular}{|c|c|c|}
\hline Cinsiyet & Frekans & Yüzde (\%) \\
\hline Kadın & 197 & 36,1 \\
\hline Erkek & 349 & 63,9 \\
\hline Toplam & 546 & 100 \\
\hline Medeni Durum & Frekans & Yüzde (\%) \\
\hline Evli & 207 & 37,9 \\
\hline Bekar & 308 & 56,4 \\
\hline Boşanmış & 18 & 3,3 \\
\hline Eşi Vefat Etmiş & 13 & 2,4 \\
\hline Toplam & 546 & 100 \\
\hline Ö̆̆renim Durumu & Frekans & Yüzde (\%) \\
\hline Okur-yazar değil & 98 & 17,9 \\
\hline Okur - yazar & 70 & 12,8 \\
\hline İlkokul & 88 & 16,1 \\
\hline Ortaokul & 79 & 14,5 \\
\hline Lise & 138 & 25,3 \\
\hline Üniversite & 71 & 12,9 \\
\hline Toplam & 546 & 100 \\
\hline Yaş & Frekans & Yüzde (\%) \\
\hline $18-25$ & 168 & 26,7 \\
\hline $26-29$ & 58 & 14,7 \\
\hline $30-39$ & 134 & 24,5 \\
\hline $40-49$ & 121 & 22,2 \\
\hline $50-60$ & 65 & 11,9 \\
\hline Toplam & 546 & 100 \\
\hline Engel türü & Frekans & Yüzde (\%) \\
\hline Ortopedik & 286 & 52,4 \\
\hline Konuşma-dil & 48 & 8,8 \\
\hline Görme & 76 & 13,9 \\
\hline İşitme & 55 & 10,1 \\
\hline Diğer & 78 & 14,3 \\
\hline Toplam & 546 & 100 \\
\hline Engel Derecesi & Frekans & Yüzde (\%) \\
\hline$\% 40-69$ & 271 & 49,6 \\
\hline$\% 70-79$ & 151 & 27,7 \\
\hline$\% 80$-ve yukarı & 112 & 20,5 \\
\hline Toplam & 546 & 100 \\
\hline Ayllk ekonomik gelir & Frekans & Yüzde (\%) \\
\hline Düzenli gelir yok & 127 & 23,3 \\
\hline Engelli Aylığı & 217 & 39,7 \\
\hline Asgari Ücret & 94 & 17,2 \\
\hline $3.000-5.000 \mathrm{TL}$ & 80 & 14,7 \\
\hline 5000 TL - daha yüksek & 26 & 4,8 \\
\hline Toplam & 546 & 100 \\
\hline
\end{tabular}

Araştırma grubunu, en az \%40 düzeyinde engel oranına sahip on sekiz yaş üstü engelli bireylerdir. Tablo 1'de cinsiyet, medeni durum, öğrenim durumu, engel türü, engel derecesi aylık 
ekonomik gelir durumuna dair bilgiler verilmiştir. Cinsiyet değişkeninde erkeklerin oranı kadınların sayısından daha fazladır. Bunun başlıca nedeni engelli kadınlara ulaşmanın oldukça güç olması ve engelli kadınların anketi cevaplamaya istekli olmayışı ile açıklanabilir. Bekar olan engelli birey sayısı evli olanlardan yüksektir. Öğrenim durumu değişkeninde dağılımın tüm düzeyler için birbirine yakın oranlarda olduğu görülmektedir ki bu durum yürütülen çalışma açısından uygun bir neticedir. Yaş değişkeni de uygun bir dağılım göstermektedir. Engel türü dikkate alındığında ortopedik engelli sayısı diğer engel türlerine göre oldukça yüksektir. Bu oranı belirleyen nedenler arasında önemli oranda, söz konusu engellilik türünün kapsamında omurga eğrilikleri, doğuştan ve travmatik uzuv kayıpları, çocuk felci, serebral palsi, omurilik felçlileri gibi birçok alt tür bulunmasıdır. Aylık ekonomik gelirinde engelli aylığında yoğunlaştığı, dolayısıyla düzenli gelir yok seçeneğiyle beraber dikkate alındığında oranın \%63'e ulaştığı anlaşılmaktadır.

Bu değişkenler ve verilerin özellikle Türkiye'de engellilerle ilgili yapılan; Özürlüler İdaresi Başkanlığı Özürlülerin Sorun ve Beklentileri Araştırması 2010, Türkiye İstatistik Kurumu Özürlülüğe Dayalı Ayrımcılığın Ölçülmesi Araştırması 2010 gibi alan araştırmalarında ortaya çıkan sonuçlarla yakın olduğu dile getirilebilir. Ayrıca söz konusu değişkenler taşıdıkları nitelikler bakımından ölçek için uygun bir araştırma grubu olduğunu da göstermektedir.

\section{Ölçeğinin Geliştirilme Süreci}

Ölçeğin hazırlanma sürecinde ilk olarak ulusal ve uluslararası literatür taranarak gerekli kaynaklarının tespiti yapılmıştır. Engellilerin yaşadıkları sorunlar ile ilgili çalışmalar gözden geçirilmiş ve bunun sonucunda olası temel kategorilere ilişkin belirlemeler ortaya çıkmıştır. Engellilikle ilgili literatür büyük oranda özel eğitim çalışmaları kapsamında gerçekleştirilmiştir. Bu noktada özellikle engellilerin yaşadıkları toplumsal sorunlar hakkındaki Türkçe literatür yanında, uluslararası literatürdeki çalışmalardan da yararlanılmıştır. Türkçe'de sosyal dışlanma ile dezavantajlı bazı gruplar (yoksullar, romanlar, mülteciler, ergenler, vb.) arasındaki ilişkinin incelendiği çeşitli çalışmalar mevcuttur (Aslan, 2016; Aydoğan, 2018; Kayalar, 2019; Şenol, 2010). Bununla birlikte sosyal dışlanma ve engelliliğe dair geniş bir literatür bulunmamaktadır. Özellikle engellilerin yaşadıkları sorunlar çeşitli değişkenler açısından araştırılmıştır. Engellilik ve sosyal dışlanma ilişkisini araştıran sınırlı sayıda tez ve makale bulunmaktadır (Ergüden, 2008; Darıyemez, 2012; Bucuka, 2017; Balc1, 2019; Çelik, 2019). Bu çalışmalar test etmek için üretilen maddelerin önemli kaynakları olmuştur. Ayrıca, ölçek geliştirme sürecinde başvurulan diğer önemli kaynaklar da şunlardır: Bayram, Aytaç, Aytaç, Sam ve Bilgel tarafından Türkçeye uyarlanan "Sosyal Dışlanma Ölçeği" (2012), Yelpaze ve Türküm'ün Türkçeye uyarladıkları "Engellilere Yönelik Çok Boyutlu Tutum Ölçeği" (2017), Kaner ve arkadaşlarının geliştirdikleri "Engellilere Yönelik Tutum Ölçeği" (1997)'dir.

Geliştirilmesi hedeflenen ölçek beşli likert tipi maddeler biçiminde oluşturulmuştur. Bu maddelere verilen cevaplar beş derecede tasnif edilmişlerdir. Bunlar; (1) Hiçbir Zaman, (2) Nadiren, (3) Bazen, (4) Çoğunlukla ve (5) Her Zaman dereceleridir (Bayat, 2014). Taslak ölçek için oluşturulan madde havuzundan toplam altmış beş madde seçilmiş ve ölçek sonraki aşamalar için düzenlenmiştir. Ölçek maddelerinin engellilerin sosyal dışlanmalarını ölçmeye uygun olup olmadığını belirlemek amacıyla uzman görüşlerine başvurulmuştur (Krysik ve Finn, 2015). Bu süreçte Bingöl Üniversitesinde işletme, eğitim bilimleri, sosyal hizmet ve sosyoloji alanlarında ölçek geliştirme ve kullanma konusunda akademik çalışmaları da bulunan yedi öğretim üyesine düzenlenen taslak ölçek incelenmesi için iletilmiştir. Bu incelemeler neticesinde altmış beş maddenin on beş maddesine ilişkin eleştiriler doğrultusunda madde sayısı elliye indirilerek ölçek maddelerine son hali verilmiştir. Elli maddelik ölçeğin anlaşılabilirlik düzeyini tespit etmek için Bingöl ilinde bulunan otuz engelli bireyüzerinde yapılan ön uygulanma sonrasında, yapılan eleştirilerle beraber imla ve ifade özellikleri, Türk Dili ve Edebiyatı öğretim üyesi tarafindan gözden geçirilerek ölçeğe son hali verilmiştir. Bu maddelerden kırk adedi olumlu on maddesi ise olumsuz olarak düzenlenmiştir. Bu maddeler herhangi bir değişken düşünülmeden gelişigüzel 
sıralanmıştır. Ölçek, "Engellilerde Sosyal Dışlanma Ölçeği (ESDÖ)" olarak adlandırılmıştır. Düzenlenen bu taslak ölçek formu, etik unsurlar açısından değerlendirilmesi için Bingöl Üniversitesi Bilimsel Araştırma ve Yayın Etiği Kurulu Başkanlığına başvurulmuş ve 14.01.2020 tarih ve E.1101 sayılı karar ile uygulanma konusunda onay alınmıştır.

\section{Verilerin Toplanması ve Analizi}

Ölçeğin sahada uygulanmasında anketörler, Bingöl Üniversitesi Sosyal Hizmet Bölümünde, "Engellilerle Sosyal Hizmet", "Araştırma Yöntem ve Teknikleri" ile "Uygulamalı Araştırma" derslerini almış ve bu bölümden mezun olmuş öğrencilerden seçilmiştir. Anket uygulayıcılarına, saha araştırmalarına başlanmadan önce araştırmanın amacı, önemi ve ölçek soruları hakkında bilgiler verilmiştir. Ayrıca anket uygulamalarda çeşitli esasları ve süreci tanımlamak amacıyla oluşturulmuş yönerge tanıtılıp paylaşılmıştır. Veri toplama için 20 anketör ve 5 saha koordinatörü olmak üzere 25 araştırmacı görev almıştır.

$\mathrm{Bu}$ süreçte altı yüz elli form çoğaltılmış anketörler vasıtasıyla sahada uygulanması için dağıtılmıştır. Ocak ve Şubat 2020 aylarında saha çalışmaları sonucunda yaklaşık altı yüz adet ölçek formu geri toplanmıştır. Bunların içinde eksik doldurulmuş olma vb. çeşitli nedenlerle elli dört adet anket değerlendirme dışında tutulmuş ve toplam 546 adet form üstünden geliştirme çalışması sürdürülmüştür.

$\mathrm{Bu}$ formlardan elde edilen veriler SPSS ve Amos programları ile analiz edilmişlerdir. Öncelikle verilerin psikometrik niteliklerini belirlemek amacıyla istatistiksel çözümlemelerle verilerin dağılımlarının normal olup olmadığına bakılmıştır. Bu doğrultuda maddelerin Skewness ve Kurtosis değerlerine bakılmış ve sonuçların -1.50 ile +1.50 olması dolayısıyla dağılımın normal ölçülerde olduğu (Can, 2013) sonucuna ulaşılmıştır. Bu süreçten sonra açımlayıcı faktör analizi (AFA) ve doğrulayıcı faktör analizi (DFA) ile ölçek, yapı geçerliliği analizine tabi tutulmuştur.

\section{Bulgular}

\section{Açımlayıcı Faktör Analizine İlişkin Bulgular}

AFA yapılmadan önce verilerin faktör analizi bakımında uygun olup olmadığının araştırılması gerekmektedir (Büyüköztürk, 2012). Bu nedenle Kaiser-Meyer-Olkin (KMO) örneklem yeterliliği ölçütü testi ve Barlett testi (Bartlett test of) sonuçları elde edilmiştir. Field'e (2009) göre KMO'nun .80 ile .90 aralığında olması değerlerin 'iyi' olduğunu belirtmektedir gerçekleştirilen analizde KMO değeri .88 ve Barlett testi $\chi 2$ değeri ise 5259,337 $(\mathrm{p}<.001)$ olarak tespit edilmiştir. $\mathrm{Bu}$ sonuçlar, KMO değerinin 'iyi' ve Barlett Küresellik Testi sonucunun ise anlamlı olduğunu göstermektedir. Dolayısıyla KMO ve Barlett değerlerinin AFA için uygun olduğu sonucuna ulaşılmıştır.

Tablo 2: Kaiser-Meyer-Olkin (KMO) Örneklem Yeterliliği

\begin{tabular}{cc}
\hline KMO değeri & Örneklem Yeterliği \\
\hline, 50 ve altı & Kabul edilemez \\
, $50-, 59$ & Çok kötü \\
, $60-, 69$ & Kötü \\
, $70-, 79$ & Orta \\
, $80-, 89$ & İyi \\
$, 90-1,00$ & Çok iyi \\
\hline
\end{tabular}

ESDÖ’nün faktör yüklerinin .32 değerin üstünde olması ayrıca bir maddenin iki farklı faktörde yeterli yük değerine sahip olması durumunda farkın minimum .10 olması göz önüne alınmıştır (Büyüköztürk, 2012). Bu referanslar dikkate alındığında, elli maddeden oluşan ölçekteki 25 madde, faktör yük değerleri yeterli olmadığından çıkarılarak, 25 maddelik ölçek oluşturulmuştur. Ölçek maddelerinin faktör analizi sonucunda, Scree plot grafiği gözden 
geçirilerek, ölçeğin üç alt boyutlu olması uygun görülmüştür. Bu analizler sonucunda elde edilen Scree plot (yamaç grafiği) de, Grafik 1'de gösterilmektedir.

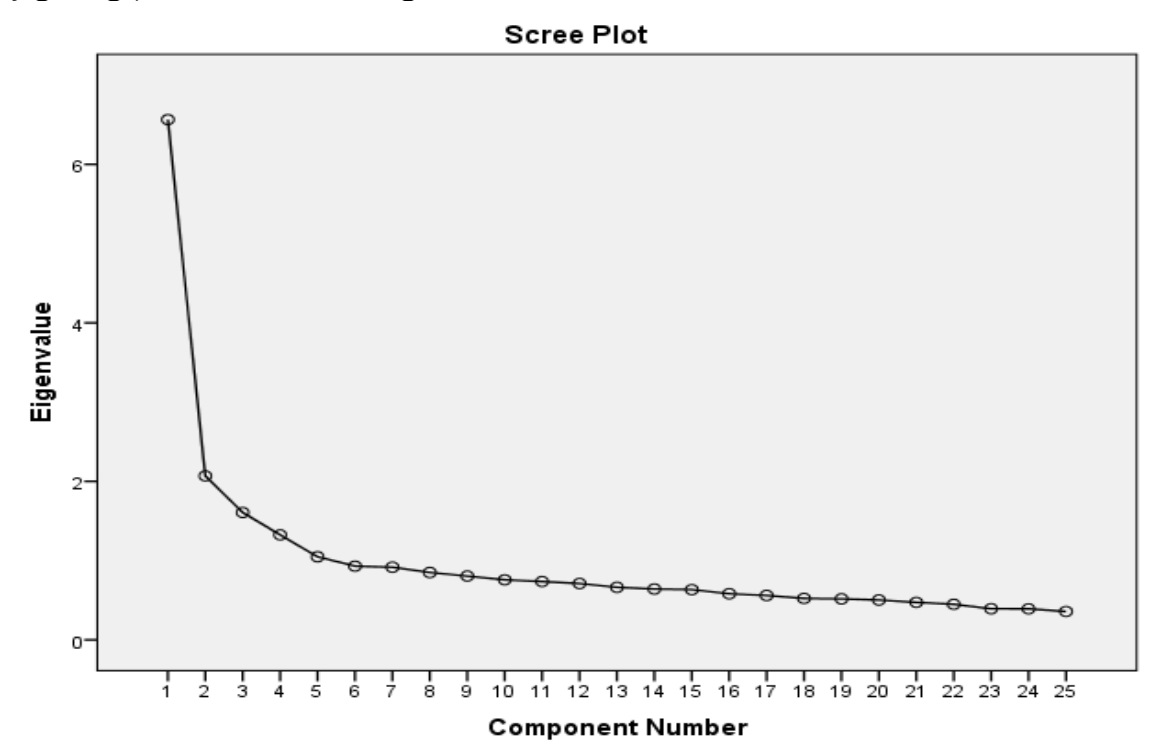

Grafik 1: ESDÖ Yamaç Grafiği

AFA sonucunda ESDÖ üç alt boyutta şekillenmiştir. Bu alt boyutlar sosyal hayata katılımdan dişlanma $(10,11,16,18,19,20,27,31,36,37$ ve 43. maddeler), temel hizmetlere erişimden dişlanma $(1,3,4,12,26,35$ ve 47 . maddeler) ile gelir yoksunluğu ve ekonomik alandan dışlanma $(2,8,9,22,28,29$ ve 30. maddeler) şeklinde adlandırılmıştır. Bu adlandırmaya temel oluşturan ilgili literatürdeki kategorilendirme ve boyutlandırmadır. Sosyal ilişkilerden, temel hizmetlere erişimden, siyasi katılım kanallarından, yakın çevreden dışlanmadır. Ayrıca sosyal dışlanmanın, çevresel, mekansal, iş piyasasına erişim, düşük gelir, yetersiz sosyal destek gibi boyutlar1 da mevcuttur (Jehoel-Gijsbers ve Vrooman, 2007; Levitas vd., 2007; Percy-Smith, 2000; Pierson, 2009; Scharf vd. 2001; Silver, 1995; Silver ve Miller 2003) olarak adlandırılmışlardır. Bu boyutları oluşturan maddelerin faktör yükleri de Tablo 3 'te sunulmuştur. 
Tablo 3: Ölçek Maddelerin Faktör Yükleri

\begin{tabular}{|c|c|c|c|c|c|}
\hline 胥 & $\begin{array}{l}\stackrel{0}{z} \\
\stackrel{0}{0}\end{array}$ & Ölçek Maddeleri & \multicolumn{3}{|c|}{ Faktör Yükleri } \\
\hline \multirow{11}{*}{ 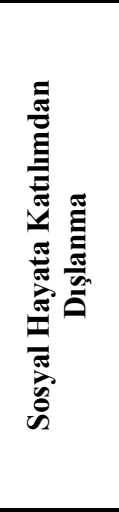 } & 20 & Kendimi toplumdan dışlanmış hissederim. & .670 & & \\
\hline & 36 & Engelim nedeniyle kalabalıktan uzak kalmayı tercih ederim. & .600 & & \\
\hline & 37 & Kamu kurumlarında (resmi daireler) kötü muameleye uğrarım. & .590 & & \\
\hline & 27 & İnsanlardan olumsuz tutum ve davranışlara maruz kalırım. & .561 & & \\
\hline & 19 & Engelli olarak yaşadığım çevrede kendimi güvende hissetmem. & .545 & & \\
\hline & 18 & Aile kurma/evlenme hususunda güçlük yaşarım. & .535 & & \\
\hline & 43 & Sağl1k çalışanlarından kötü muamele görürüm. & .535 & & \\
\hline & 10 & Sosyal ilişki kurduğum insan sayısı azdır. & .517 & & \\
\hline & 31 & Aile içi kararların alınmasında görüşlerim dikkate alınmaz. & .477 & & \\
\hline & 11 & Eğitim sürecinde arkadaşlarımdan gördüğüm destek yetersizdir. & .472 & & \\
\hline & 16 & Öğretmenlerden olumsuz tutum ve davranışlara maruz kalırım. & .441 & & \\
\hline \multirow{7}{*}{ 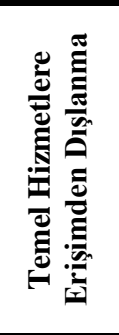 } & 4 & Yaşadığım yerin yol ve kaldırım gibi unsurlarını kullanmak zordur. & & .753 & \\
\hline & 12 & Hastanelerin fiziki/mimari yapısından dolayı güçlük çekerim. & & .688 & \\
\hline & 26 & Okulların binası/fiziki koşulları engellim için uygun değildir. & & .662 & \\
\hline & 47 & Toplu ulaşım araçlarını kullanırken güçlük çekerim. & & .648 & \\
\hline & 1 & $\begin{array}{l}\text { Kamu hizmeti (resmi daireler) veren binaları kullanırken sıkıntı } \\
\text { cekerim. }\end{array}$ & & .628 & \\
\hline & 35 & Sağllk hizmetlerine ulaşmakta zorluk yaşarım. & & .520 & \\
\hline & 3 & Engelime uygun yeterli sağlık hizmeti alamıyorum. & & .408 & \\
\hline \multirow{7}{*}{ 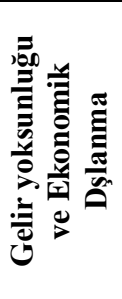 } & 30 & Ekonomik geleceğim konusunda endişe yaşarım. & & & .756 \\
\hline & 29 & Engelimle ilgili sağlık giderleri maddi gücümü zorlamaktadır. & & & .707 \\
\hline & 8 & Aniden ortaya çıkacak masraflar bana maddi sıkıntı oluşturur. & & & .704 \\
\hline & 2 & İş bulma konusunda zorluk yaşarım. & & & .541 \\
\hline & 9 & Devletin engellilere verdiği destekler yetersizdir. & & & .510 \\
\hline & 22 & Borç para bulmada sıkıntı çekerim. & & & .502 \\
\hline & 28 & Ekonomik imkânım olursa ikamet ettiğim mahalleyi değiştiririm. & & & .480 \\
\hline
\end{tabular}

ESDÖ’nün faktör yapısı analiz edilirken, ölçek maddelerin faktör yüklerinin .32 üstünde olmasına ve farklı iki faktörde yeterli değere sahip maddelerde ise, her iki değer arasındaki farkın en az .10 olması ön plana alınmıştır (Büyüköztürk, 2012). Bu referans değerler dikkate alındığında, taslak ölçekte bulunan önermelerden yirmi beş madde yeterli değere sahip olmadığından çıkarılmış ve nihai olarak yirmi beş maddeden oluşan forma ulaşılmıştır. Böylece, AFA sonucunda ölçek yirmi beş madde ve üç boyuttan oluşmuştur. Ölçeğin açıkladığı toplam varyans oranı \%40,94 olarak belirlenmiştir. Tüm maddelerin faktör yüklerine bakıldığında ise en düşük değer .408 ve en yüksek değer ise .756 olarak tespit edilmiştir.

\section{Doğrulayıcı Faktör Analizine İlişkin Bulgular}

AFA neticesinde ortaya çıkan üç boyut ve yirmi beş madde DFA'ya tabi tutulmuştur. Elde edilen DFA sonuçları Şekil 2'de sunulmuştur. DFA için, ölçeğin geçerliliğini belirlemek amaciyla çeşitli uyum indekslerinden ( $\mathrm{x}^{2}$, IFI, CFI, GFI, AGFI, RMSEA vb.) yararlanılmaktadır. Bu indekslerin uyum değerleri; RMSEA için 0.05 iyi ve CFI, IFI, AGFI ve GFI indeksleri için 0.90 kabul edilebilir, 0.95 ve üzeri değer ise iyi uyum değeri olarak kabul görmektedir (Bayram, 2016). Analiz neticesinde, ölçeğin uyum indekslerinin anlamlı $\left(\mathrm{x}^{2} / \mathrm{sd}=2,000, \mathrm{p}=.00\right)$ ve kabul edilebilir uyum değerine sahip olduğu belirlenmiş̧ir. Uyum indeks değerleri için sonuçlar RMSEA=.043, $\mathrm{CFI}=.92, \mathrm{IFI}=.92, \mathrm{AGFI}=.91$ ve $\mathrm{GFI}=.93$ değerinde tespit edilmiştir. Ayrıca, 37. ve 43. maddeler 
arasında da modifikasyon önerileri doğrultusunda işlem gerçekleştirilmiş ve modelin modifikasyon işleminin ardından iyi uyum verdiği saptanmıştır.

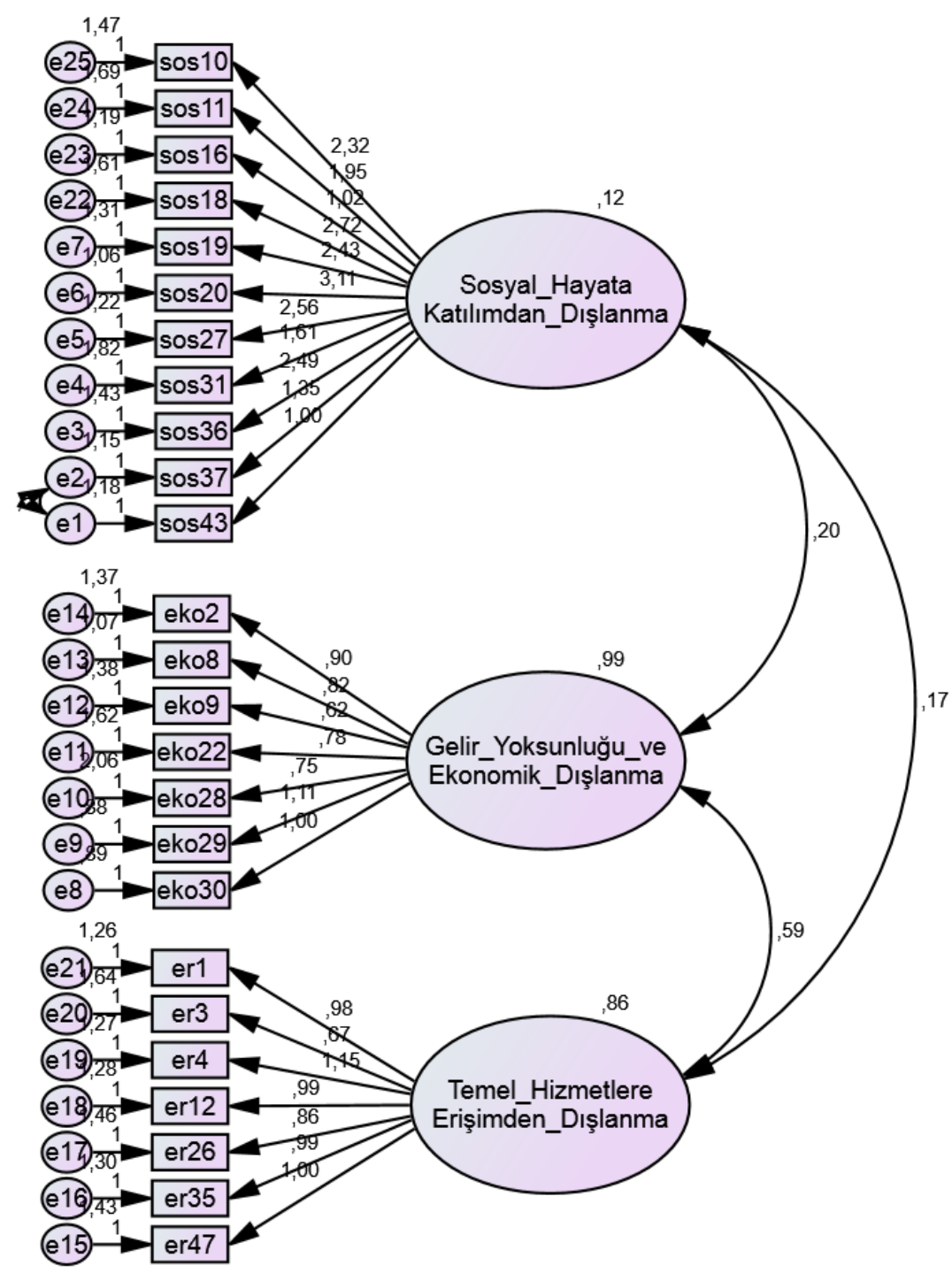

Şekil 1: Ölçeğin DFA Değerleri

\section{Ölçeğin Güvenirlik Analizine İlişkin Bulgular}

ESDÖ, likert tipi maddelerden oluştuğu için ölçeğin güvenirlik analizi Cronbach alpha alpha güvenirlik katsayısı ile yapılmıştır (Şeker ve Gençdoğan, 2014: 47). De Vellis'in (2014: 109) belirttiği katsayı ve değerler aşağıda tablo olarak verilmiştir.

Tablo 4: Cronbach Alpha Güvenirlik Katsayısı Kabul Edilebilirlik Düzeyi

\begin{tabular}{cc}
\hline Cronbach Alpha Güvenirlik Katsayısı & Kabul Edilebilirlik Değeri \\
\hline .60 ve altı & Kabul edilemez \\
.60 ve .65 & Yeterli olmayan \\
.65 ve .70 & Kabul edilebilir \\
.70 ve .80 & Kayda değer \\
.80 ve .90 & Çok iyi \\
.90 ve üstü & Mükemmel \\
\hline
\end{tabular}

Turkish Studies - Social, 15(5) 
$\mathrm{Bu}$ değerler referans alındığında ölçeğin toplam Cronbach-alfa güvenirlik katsayısı .88 ile çok iyi bir katsayı değerine sahip olduğu söylenebilir. Ayrıca ölçeğin alt boyutlarının Cronbachalfa güvenirlik katsayıları ise Tablo 5 'te verilmiştir. Bu sonuçlara göre yirmi beş maddeli ve üç alt boyutlu ESDÖ'nün güvenirlik düzeyinin istenilen nitelikte olduğu ifade edilebilir.

Tablo 5: Engellilerde Sosyal Dıșlanma Ölçeği Cronbach Alpha Değerleri

\begin{tabular}{lc}
\hline Engellilerde Sosyal Dışlanma Ölçeği Alt Boyutlar & Cronbach Alpha \\
\hline Sosyal Hayata Katılımdan Dışlanma & .80 \\
Temel Hizmetlere Erişimden Dışlanma & .78 \\
Gelir Yoksunluğu ve Ekonomik Alandan Dışlanma & .79 \\
\hline ESDÖ/ TOPLAM & $\mathbf{. 8 8}$ \\
\hline
\end{tabular}

\section{ESDÖ Puanlanması ve Değerlendirilmesi}

ESDÖ üç alt boyuttan oluşmaktadır. Ölçeğin, sosyal hayata katılımdan dışlanma alt boyutunda on bir madde; temel hizmetlere erișimden dişlanma alt boyutunda yedi ve gelir yoksunluğu ve ekonomik alandan dişlanma alt boyutunda yedi olmak üzere toplam yirmi beş madde bulunmaktadır. Bu maddelerin tümü olumlu (pozitif yönlü) yani ters madde değildirler. Ölçeğin en yüksek puanı 125 , en düşük puanı ise 25 'tir. Bu nedenle ölçek, çeşitli engelli gruplarına uygulandığında ortalama puan yükseldikçe engellilerin yaşadıkları sosyal dışlanma derecesinin de arttığ söylenebilir.

\section{Sonuç}

ESDÖ, geliștirme sürecinde, ilgili literatür tarandı, madde havuzu ve maddelerden de aday maddeler oluşturuldu. Dil ve anlatım, kapsam, içerik yönünden uzman değerlendirmeleri yapıldı. Ölçek meddeleri açımlayıcı analize tabi tutuldu. Örneklemin yeterliliği için Kaiser-Meyer-Olkin (KMO) örneklem yeterliliği testi uygulandı. Maddelerin faktör yüklerine bakıldı yeterli değer sahibi olmayanlar ölçekten çıkarıldı. Maddelerinin faktör analizi sonucunda, Scree plot grafiği gözden geçirilerek, ölçeğin üç alt boyutlu olması uygun görülmüştür. Doğrulayıcı faktör analizi ve ölçeğin güvenirlilik çalışmaları için Chronbach alpha güvenirlik analizleri gerçekleştirildi.

Çalışmada, elli maddeden oluşan taslak ESDÖ, 546 engelli bireyin değerlendirmesi yoluyla geliştirilmiştir. $\mathrm{Bu}$ süreç sonucunda yirmi beş madde ve üç alt boyuttan oluşan bir ölçek elde edilmiştir. Alt boyutlar literatürden yararlanarak sosyal hayata katılımdan dışlanma, temel hizmetlere erişimden dişlanma ile gelir yoksunluğu ve ekonomik alandan dişlanma (JehoelGijsbers ve Vrooman, 2007; Levitas vd., 2007; Percy-Smith, 2000; Pierson, 2009; Scharf vd. 2001; Silver, 1995; Silver ve Miller 2003) olarak adlandırılmışlardır.

Yapılan analizler neticesinde şu sonuçlara ulaşılmıştır. Ölçeğin toplam varyans oranı $\% 40,94$ olarak belirlenmiştir. Ölçek maddelerin faktör yükleri .40 ile .75 arasında değer almışlardır. Doğrulayıcı faktör analizinde ölçeğin yeterli uyum indeksi değerleri taşıdığı ve ölçeğin alt boyutlarının Cronbach Alpha katsayıları ise .80 , .78 ve .79 olarak tespit edilmiştir. Ölçeğin, maddelerinin faktör analizinde KMO değeri .88 ve Barlett testi $\chi 2$ değeri ise 5259,337 $(\mathrm{p}<.001)$; Cronbach-alpha güvenirlik analizinde katsayısı .88 ve ölçeğin uyum indekslerinin analizinde $\left(\mathrm{x}^{\wedge} 2 / \mathrm{sd}=2,000, \mathrm{p}=.00\right)$ anlamlı ve kabul edilebilir düzeyde olduğu ortaya konmuştur. Güvenirlik ve geçerlilik analizleri sonucunda, ölçeğin uygulanabilir bir araç olduğunu ortaya koymuştur.

Geliștirilen bu ölçek engellilerin yaşadıkları sorunları tespit ve derecelendirme hususunda yeterliliğe sahiptir. Özellikle engellilerin, sosyal hayata katılmaları, temel hizmetlere erişim düzeylerini, gelir yoksunluğu ve ekonomik durumlarını ölçmek için önemli maddeler içerdiği ve yapılacak ölçümlerle engellilere sunulacak hizmetlerin yön ve yoğunluğunun belirlenmesinde kuşkusuz faydalar sağlayacaktır. Böylece gerek kamu hizmetleri gerekse de yakın sosyal ilişkiler 
bağlamında formel ve enformel desteklerin, engellilerin yaşam memnuniyetlerini arttıracağı da dile getirilebilir.

Gerçekleştirilecek yeni çalışmalarla engellilerin sosyal dışlanma düzeyleri ile çeşitli değişkenler arasındaki ilişkiler ortaya konabilecektir. Ölçeğin, daha ileri düzeydeki, müdahale ve rehabilitasyon süreçleri gibi çalışmalarda, ön test-son test uygulamaları ile doğrulayıcı veriler ortaya koyması da muhtemeldir.

\section{Kaynakça}

2828 Sayılı Sosyal Hizmetler Kanunu. (1983). T. C. Resmi Gazete, 18059, 24 Mayıs 1983.

Alpar, R. (2013). Uygulamalı çok değişkenli istatistiksel yöntemler. Detay Yayıncılık.

Aslan, S. (2016). Sosyal dışlanma bağlamında genç suçluluğu, Yayınlanmamış yüksek lisans tezi, Akdeniz Üniversitesi Sosyal Bilimler Enstitüsü.

Aydoğan, R. (2018). Cezaevi sonrası denetimli serbestlik sürecindeki hükümlülerin suç, damga ve sosyal dışlanma bağlamında incelenmesi, Yayınlanmamış yüksek lisans tezi, Mimar Sinan Güzel Sanatlar Üniversitesi Sosyal Bilimler Enstitüsü.

Balcı, S. (2019). Engellilerin sosyal dışlanma durumu: Araklı örneği. Yayımlanmamış yüksek lisans tezi, Gümüşhane Üniversitesi Sosyal Bilimler Enstitüsü.

Bayat, B. (2014). "Uygulamalı sosyal bilim araştırmalarında ölçme, ölçekler ve "likert" ölçek kurma tekniği". Gazi Üniversitesi İktisadi ve İdari Bilimler Fakültesi Dergisi, 16/3, 1-24.

Bayram, N. (2016). Yapısal eşitlik modellemesine giriş: Amos uygulamaları. Ezgi Kitabevi.

Bayram, N., Aytaç, S., Aytaç, M., Sam, N., \& Bilgel, N. (2012). "Poverty, social exclusion, and life satisfaction: a study from Turkey". Journal of Poverty, 16(4), 375-391.

Bhalla, A., \& Lapeyre, F. (1997). "Social exclusion: Towards an analytical and operational framework". Development And Change, 28(3), 413-433.

Bolger, J., \& P. Morago (2016). "Poverty and social exclusion", in Social Policy for Social Work, Social Care and The Caring Professions (Ed. S. Hothersall \& J. Bolger), Routledge, pp. 107124.

Bradshaw, J., P. Kemp, S. Baldwin \& A. Rowe (2004). The drivers of social exclusion. a review of the literature for the social exclusion unit in the breaking the cycle series, Office of the Deputy Prime Minister.

Bucuka, Y. (2017). Dini sosyalleşme ve sosyal dışlanma ekseninde engellilik (Bingöl ili örneği). Yayımlanmamış doktora lisans tezi, Atatürk Üniversitesi, Sosyal Bilimler Enstitüsü.

Burcu, E. (2010). "Engellilik modelleri üzerine". Nevin Güngör Ergan, Esra Burcu, Birsen Şahin (Ed.), Sosyoloji Yazıları 3 (ss: 69-81) içinde. Hacettepe Üniversitesi Yayınları.

Büyüköztürk, Ş. (2012). Sosyal bilimler için veri analizi el kitabı. Pegem Akademi.

Can, A. (2013). SPSS ile bilimsel araştırma sürecinde nicel veri analizi. Pegem Akademi.

Çelik, F. (2019). Bedensel engellilerde sosyal dışlanma ve benlik saygısı ilişsisi: Adıyaman ili örneği. Yayımlanmamış yüksek lisans tezi, Sivas Cumhuriyet Üniversitesi Sosyal Bilimler Enstitüsü. 
Darıyemez, M. (2012). Sosyal dışlanma bağlamında engellilerin çalışma hayatından soyutlanmast: Antalya örneği. Yayımlanmamış yüksek lisans tezi, Süleyman Demirel Üniversitesi Sosyal Bilimler Enstitüsü.

De Haan, A. (1999). Social exclusion: Towards an holistic understanding of deprivation. https://www.researchgate.net/publication/44824462_Social_Exclusion_ $\quad$ Towards_a_ Holistic_Understanding_of_Deprivation (Erişim Tarihi: 12.03.2020).

De Vellis, R. F. (2014). Ölçek geliştirme: Kuram ve uygulamalar (T. Totan, Çev.). Nobel Yayınc1lik.

Devlet İstatistik Enstitüsü (2002). Türkiye Özürlüler Araştırması. DİE.

Dünya Sağl1k Örgütü (2011). Dünya Engellilik Raporu. https://static.ohu.edu.tr/uniweb/ media/ portallar/engelsizuniversite/duyurular/1345/diwnu3i5.pdf (Erişim Tarihi: 10.01.2020).

Ergüden, A. D. (2008). Sosyal dışlanma açısından bedensel engelli bireylerin yaşantılarının incelenmesi. Yayımlanmamış yüksek lisans tezi, Hacettepe Üniversitesi Sosyal Bilimler Enstitüsü.

Field, A. P. (2009). Discovering statistics using SPSS: And sex and drugs and rock ' $n$ ' roll. London: Sage publications.

Jehoel-Gijsbers, G., \& Vrooman, C. (2007). Explaining social exclusion a theoretical model tested in the Nederlands. https://www.researchgate.net/publication/236981206_Explaining_Social_ Exclusion_A_Theoretical_Model_Tested_in_The_Netherlands (Erişim Tarihi: 15.01.2020).

Kaner, S., Öğülmüş, S., Büyüköztürk, Ş., \& Dökmen, Z. (1997). Toplum özürlülüğü nasıl algıllyor temel araştırması. T.C. Başbakanlık Özürlüler İdaresi Başkanlığı, Ankara. https://www.ailevecalisma.gov.tr/media/2622/toplum-ozurlulugu-nasil-anliyor-arastirmaprojesi-sonuclari.pdf (Erişim Tarihi: 11.01.2020).

Kayalar, T. (2019). Yoksulluk bağlamında kadınların sosyal dışlanma deneyimleri, Yayınlanmamış doktora tezi, Ankara Yıldırım Beyazıt Üniversitesi Sağlık Bilimleri Enstitüsü.

Klasen, S. (1998). Social exclusion and children in OECD countries: some conceptual issues. Erişim Tarihi: 14.03.2020, http://www.oecd.org/edu/school/1856923.pdf (Erişim Tarihi: 10.11.2019).

Krysik, J. L., \& Finn, J. (2015). Etkili uygulama için sosyal hizmet araştırması. (E. Erbay, Çev.) Nika Yayıncılık.

Levitas, R., Pantazis, C., Fahmy, E., Gordon, D., Lloyd-Reichling, E., \& Patsios, D. (2007). The multi-dimensional analysis of social exclusion. https://dera.ioe.ac.uk/6853/1/ multidimensional.pdf (Erişim Tarihi: 20.02.2020).

Mathieson, J., Popay, J., Enoch, E., Escorel, S., Hernandez, M., Johnston, H., \& Rispel, L. (2008). Social exclusion meaning, measurement and experience and links to health inequalities. http://www.who.int/social_determinants/media/sekn_meaning_measurement_experience_ 2008.pdf (Erişim Tarihi: 10.01.2020).

Mitchell, D., \& Snyder, S. (2003). "The eugenic atlantic: Race, Disability, and the making of an international eugenic science, 1800-1945". Disability \& Society, 18 (7), 843-864.

Okur, N., Erbilerdugan, F. (2010). "Sosyal haklar ve özürlüler: özürlülük modelleri bağlamında tarihsel bir değerlendirme". Mesut Gülmez (Ed.). Sosyal Haklar Ulusal Sempozyum Bildirileri, 4-6 Kasım 2010, (ss: 245-263), İstanbul: Petrol-İs. http://www.sosyalhaklar.net/ 2010/bildiri/okur.pdf (Erişim Tarihi: 05.01.2020). 
Özürlüler İdaresi Başkanlığı. (2010). Özürlülüğe Dayalı Ayrımcılığın Ölçülmesi Araştırması. ÖZİDA.

Percy-Smith, J. (2000). Policy responses to social exclusion: Towards inclusion?. Mcgraw-Hill Education (UK).

Pierson, J. (2002). Tackling social exclusion. Routledge.

Scharf, T., Phillipson, C., Kingston, P., \& Smith, A. E. (2001). "Social exclusion and older people: Exploring the connections". Education And Ageing, 16 (3), 303-320.

Shakespeare, T. (2011). "Sakatlık kuramı: Kilit fikirler, meseleler ve düşünürler". Dikmen Bezmez, Sibel Yardımcı, Yıldırım Şentürk (Ed.), Sakatlık Çalışmaları: Sosyal Bilimlerden Bakmak (ss: 31-60) içinde. Koç Üniversitesi Yayınları.

Silver, H. (1995). "Reconceptualizing social disadvantage: Three paradigms of social exclusion". In Jose B. Figueiredo (Eds.), Social Exclusion: Rhetoric Reality Responses (pp: 57-80), Geneva: International Labour Organization (International Institute for Labour Studies).

Silver, H. (2007). "Social Exclusion", In George Ritzer (Ed.), Blackwell Encyclopedia Of Sociology (pp:4419-4421). Blackwell Publishing.

Silver, H., \& Miller, S., M. (2003). "Social Exclusion: The European Approach to Social Disadvantage". Indicators, 2(2), pp. 5-21.

Şeker, H., Gençdoğan, B. (2014). Psikolojide ve eğitimde ölçme aracı geliştirme (2. Basım). Nobel Yayıncilik.

Şenol, E. (2010). İşsizliğin sosyal dışlanma üzerindeki etkileri, Yayınlanmamış doktora tezi, Gazi Üniversitesi Sosyal Bilimler Enstitüsü.

TBMM (2005, güncelleme 2014). Engelliler ve bazı kanun ve kanun hükmünde kararnamelerde değişiklik yapılması hakkında kanun (Engelliler kanunu). Güncelleme 2014. Kanun Numarası: 5378. Onay Tarihi: 01.07.2005, Resmi Gazete Tebliği: 07.07.2005, Konu: 25868.

Turnbull, A., Turnbull, H. R., Wehmeyer, M. L., \& Shogren, K. A. (2020). Exceptional lives: Practice, progress, \& dignity in today's schools, 9th Edition, Hoboken, Pearson Education, Inc.

Türkiye İstatistik Kurumu (2010). Özürlülerin sorun ve beklentileri araştırması. TUİK.

Uluocak, Ş., Aslan, C. (2012). Toplum ve engelliler. Çanakkale Kitaplı̆̆ı.

Yelpaze, İ., Türküm, A., S. (2018). Adaptation and validation of Turkey version of multidimensional attitudes toward persons with disabilities. OPUS Uluslararası Toplum Araştırmaları Dergisi, 8(14), 167-187. 


\section{EK 1: Engellilere Sosyal Dışlanma Ölçeği (ESDÖ)}

\begin{tabular}{|c|c|c|c|c|c|c|}
\hline$\stackrel{0}{\mathbf{Z}}$ & $\begin{array}{l}\text { Assağıda yirmi beş ifade bulunmaktadır. Her bir ifade için işaretlemeniz gereken } \\
\text { 1'den 5'e kadar rakamlar verilmiştir. Her ifadenin sizin için ne kadar doğru } \\
\text { olduğunu veya olmadığını belirtmek için yalnız bir rakamı işaretleyiniz. Lütfen } \\
\text { hiçbir cümleyi cevapsız bırakmayınız. }\end{array}$ & 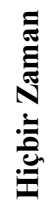 & 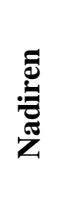 & 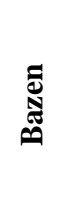 & U & 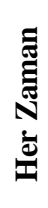 \\
\hline 1 & Engelime uygun yeterli sağlık hizmeti alamıyorum. & 1 & 2 & 3 & 4 & 5 \\
\hline 2 & Aniden ortaya çıkacak masraflar bana maddi sıkıntı oluşturur. & 1 & 2 & 3 & 4 & 5 \\
\hline 3 & Yaşadığım yerin yol ve kaldırım gibi unsurlarını kullanmak zordur. & 1 & 2 & 3 & 4 & 5 \\
\hline 4 & Engelim nedeniyle kalabalıktan uzak kalmayı tercih ederim. & 1 & 2 & 3 & 4 & 5 \\
\hline 5 & Engelimle ilgili sağlık giderleri maddi gücümü zorlamaktadır. & 1 & 2 & 3 & 4 & 5 \\
\hline 6 & Okulların binas1/fiziki koşulları engellim için uygun değildir. & 1 & 2 & 3 & 4 & 5 \\
\hline 7 & Kamu kurumlarında (resmi daireler) kötü muameleye uğrarım. & 1 & 2 & 3 & 4 & 5 \\
\hline 8 & Hastanelerin fiziki/mimari yapısından dolayı güçlük çekerim. & 1 & 2 & 3 & 4 & 5 \\
\hline 9 & Borç para bulmada sıkıntı çekerim. & 1 & 2 & 3 & 4 & 5 \\
\hline 10 & İnsanlardan olumsuz tutum ve davranışlara maruz kalırım. & 1 & 2 & 3 & 4 & 5 \\
\hline 11 & Eğitim sürecinde arkadaşlarımdan gördüğüm destek yetersizdir. & 1 & 2 & 3 & 4 & 5 \\
\hline 12 & Devletin engellilere verdiği destekler yetersizdir. & 1 & 2 & 3 & 4 & 5 \\
\hline 13 & Engelli olarak yaşadığım çevrede kendimi güvende hissetmem. & 1 & 2 & 3 & 4 & 5 \\
\hline 14 & Kamu hizmeti (resmi daireler) veren binaları kullanırken sıkıntı çekerim. & 1 & 2 & 3 & 4 & 5 \\
\hline 15 & Aile kurma/evlenme hususunda güçlük yaşarım. & 1 & 2 & 3 & 4 & 5 \\
\hline 16 & İş bulma konusunda zorluk yaşarım. & 1 & 2 & 3 & 4 & 5 \\
\hline 17 & Sağlık hizmetlerine ulaşmakta zorluk yaşarım. & 1 & 2 & 3 & 4 & 5 \\
\hline 18 & Kendimi toplumdan dışlanmış hissederim. & 1 & 2 & 3 & 4 & 5 \\
\hline 19 & Ekonomik imkânım olursa ikamet ettiğim mahalleyi değiştiririm. & 1 & 2 & 3 & 4 & 5 \\
\hline 20 & Sağlık çalışanlarından kötü muamele görürüm. & 1 & 2 & 3 & 4 & 5 \\
\hline 21 & Öğretmenlerden olumsuz tutum ve davranışlara maruz kalırım. & 1 & 2 & 3 & 4 & 5 \\
\hline 22 & Sosyal ilişki kurduğum insan sayısı azdır. & 1 & 2 & 3 & 4 & 5 \\
\hline 23 & Aile içi kararların alınmasında görüşlerim dikkate alınmaz. & 1 & 2 & 3 & 4 & 5 \\
\hline 24 & Toplu ulaşım araçlarını kullanırken güçlük çekerim. & 1 & 2 & 3 & 4 & 5 \\
\hline 25 & Ekonomik geleceğim konusunda endişe yaşarım. & 1 & 2 & 3 & 4 & 5 \\
\hline
\end{tabular}

